\title{
Eksperimental Adsorpsi dan Absorpsi Air Permukaan menggunakan Komposit hibrida Batu Basalt/ Moringa oleifera/ Tepung Lengket
}

\author{
Allesandro Rustamin Tarigan'1), I D. G. Ary Subagia ${ }^{1)^{\star}}$, AAIA Sri Komaladewi ${ }^{1)}$ \\ 1)Jurusan Teknik Mesin Universitas Udayana, Kampus Bukit Jimbaran Bali \\ Naskah diterima 29/01/2019; direvisi 02/042019; disetujui 29/04/2019 \\ doi: https://doi.org/10.24843/JEM.2019.v12.i01.p04
}

\begin{abstract}
Abstrak
Pada penelitian ini, komposit hibrida sebagai adsorbsi dan absorpsi polutan pada air permukaan telah dibuat. Komposisi hibrida terdiri dari batu basalt (BB) dan moringa oleifera (MO) sebagai pengisi dan tepung lengket (TL) sebagai matrik. Komposisi fraksi berat yaitu 40 wt\% pengisi dan 60 wt\% matrik telah diaplikasikan. Proses pencetakan panas (hot-press) telah digunakan untuk memproduksi komposit hibrida masing-masing variasi dengan melalui suhu $200^{\circ}$ Celcius dan tekanan 2000 psi. Tujuan penelitian menginovasi kemampuan bahan dalam fungsi sebagai penyerap dan pengikat polutan pada air permukaan. Perendaman komposit hibrida selama 14 hari pada air permukaan telah dilakukan untuk menguji sifat adsorpsi dan absorpsi. Turbidity dilakukan untuk menentukan nilai kekeruhan dan nilai kandungan micro-organisme pada air permukaan sebelum dan setelah penambahan komposit hibrida. Hasil pengujian ditunjukan pertambahan paling tinggi yaitu pada spesimen dengan komposisi $40 \%$ batu basalt dan $60 \%$ tepung lengket dengan pertambahan berat sebesar 21,11 gram selama 336 jam dan paling kecil pada spesimen dengan komposisi $40 \%$ moringa oleifera dan $60 \%$ tepung lengket dengan pertambahan berat sebesar 4,15 gram selama 336 jam. Pada air dilakukan pengujian terhadap kekeruhan, $\mathrm{pH}$ dan bakteri pada air setelah dilakukan pengujian, dimana hasil pada spesimen dengan komposisi $40 \%$ moringa oleifera dan $60 \%$ tepung dapat mengurangi bakteri coliform sebesar $78,6 \%$.
\end{abstract}

Kata kunci: Adsorpsi, Absorpsi, Komposit Hibrida, Poluttan, Air Permukaan

\section{Abstract}

In this research, the hybrid composite as the tool to adsorb and absorb the poluttans in surface water have been made. The hybrid composition is consisted of basalt and moringa oleifera with filler wood flour as a matrix. The composition of heavy fractions is $40 \mathrm{wt} \%$ filler and $60 \mathrm{wt} \%$ matrix has been applied. The hot-press process has been used to produce hybrid composites of each variation through a temperature of $200^{\circ}$ Celsius and a pressure of 2000 psi. The purpose of this research is to inovate the ability of materials to function as absorbent and as binder of pollutants in surface water. Immersion of hybrid composites for 14 days in surface water has been carried out to test the characteristic of adsorption and absorption. Turbidity is done to determine the turbidity value and the value of micro-organism content in surface water before and after the addition of hybrid composites. The test results showed the highest increase in the specimens with a composition of $40 \%$ basalt stone and $60 \%$ sticky flour with a weight gain of 21.11 grams for 336 hours and the smallest in specimens with a composition of $40 \%$ moringa oleifera and $60 \%$ wood flour with weight gain amounting to 4.15 grams for 336 hours. In the water testing of turbidity, pH and bacteria on water after testing, the results on specimens with a composition of $40 \%$ moringa oleifera and $60 \%$ wood flour can reduce coliform bacteria by $78.6 \%$.

Keyword: Adsorpsi, Absorption, Hybrid Composite, Poluttans, Surface Water

\section{Pendahuluan}

Teknologi pengolahan air telah berkembang sangat pesat saat ini, yang disebabkan semakin menurunnya kualitas dan kuantitas air. Berbagai inovasi telah dikembangkan guna mengurangi polutan pada air [1]. Bentuk filter pembersih air yang telah dikembangkan seperti filtrasi membran menggunakan moringa oleifera, filtrasi dengan membran tersebut telah cukup efektif memerbaiki kualitas air permukaan seperto membebaskan air dari mikro-organisme, bau dan kekeruhan. Akan tetapi dari semua alat pembersih air yang telah dikembangkan belum mampu membersihkan polutan yang terkandung pada air secara bersamaan.

Adsorpsi dan absorpsi merupakan metode yang dikembangkan sebagai filtrasi air. Beberapa studi untuk teknik adsorpsi dan absorpsi dalam perbaikan kualitas air telah dilakukan seperti; Dian dkk [2] melakukan penjernihan air menggunakan bahan batu zeolit dengan metode adsorpsi. Hasil penelitian dihasilkan bahwa proses adsorpsi pada limbah batik dengan zeolit alam akan teraktivasi dengan larutan $\mathrm{K}_{2} \mathrm{CrO}_{7} 80 \mathrm{ppm}$ pada kolom adsorpsi sebesar $78.07 \%$ dan logam $\mathrm{Cr} 14,68$ ppm sebesar 78,45\%. Kemudian Hasni dkk [3] menunjukkan bahwa proses adsorpsi Fe menggunakan zeolit alam Banda Aceh yang telah teraktivasi $\mathrm{H}_{2} \mathrm{SO}_{4}$ dengan variasi ukuran partikelnya 20, 40, 60 dan 80 mesh menggunakan larutan sampel buatan $1,25 \mathrm{mg} / \mathrm{l}$ pada waktu $30,50,80,100$ menit mendapatkan penyerapan zeolit terbaik dengan 80 mesh dan waktu 100 menit dengan tingkat removal $58,5 \%$.

Pri Andi dkk [4] menjelaskan dari hasil penelitian dengan aktivasi zeolit menggunakan $\mathrm{HCL}$ dengan variasi suhu $200,400,600^{\circ} \mathrm{C}$ didapati hasil terbaik pada temperatur $600^{\circ} \mathrm{C}$ dengan persentase $82,7 \%$.

Saat ini, sejalan himbauan pemerintah kembali menggunakan bahan alami (natural), pada penelitian 
ini dikembangkan bahan pembersih air permukaan berbasis komposit hibrida. Inovasi teknologi bahan pembersih air dikembangkan dengan memanfaatkan keunggulan dari batu basalt (BB) dan moringa oleifera (MO) dalam adsorpsi dan absorpsi polutan.

Moringa oleifera mengandung zat aktif 4-alfa4rhanmosyloxy-benzil-isothiocyanate digunakan untuk menyerap dan menetralisir partikel lumpur dan mengendapkan kandungan usur logam berat yang cukup tinggi pada air permukaan, dengan pengubahan bentuk menjadi yang lebih kecil, maka zat aktif dari moringa oleifera tersebut akan semakin banyak karena luas permukaan moringa oleifera semakin besar [5], sehingga air dapat memenuhi standar baku air bersih sesuai dengan Keputusan Menteri Kesehatan Republik Indonesia nomor 32 tahun 2017 [6].

Sri Ulfah menunjukkan bahwa penambahan moringa oleifera telah mampu menurunkan kadar besi adalah sebanyak 6 moringa oleifera dalam larutan uji besi dengan konsentrasi 100 ppm [7].

Amagloh menjelaskan bahwa bubuk dari moringa oleifera memiliki kemampuan untuk menggumpalkan sama baiknya dengan tawas, hanya saja dosis bubuk moringa oleifera yang digunakan lebih sedikit dibandingkan dosis tawas sehingga moringa oleifera dapat dijadikan sebagai koagulan alternatiff [8].

Menurut Muyibi, Suleyman dan Evison biji kelor sangat potensial saat digunakan untuk pengolahan air limbah domestik di negara berkembang [9].

Dewasa sekarang ini, disamping penggunaan moringa sebagai bahan pembersih air, juga banyak dikembangkan bahan batuan, salah satunya adalah penggunaan batu basalt. Batu basalt merupakan salah satu jenis batuan beku yang terbentuk dari pembentukan magma yang ada di permukaan bumi yang bersifat basa. Batu basalt dapat kita bedakan menjadi 2 dengan melihat dari kandungan $\mathrm{Na}_{2}$ dan $\mathrm{K}_{2} \mathrm{O}$. untuk yang mempunyai kandungan $\mathrm{Na}_{2}$ dan $\mathrm{K}_{2} \mathrm{O}$ yabg kebih tinggi disebut dengan alkali yang yang lebih rendah disebut theolitik. Batu basalt berwarna abu-abu hingga hitam, bersifat keras dan padat (masif). Batu basalt mempunyai memiliki kandungan $\mathrm{SiO}_{2}$ yang tinggi, dimana kandungan $\mathrm{SiO}_{2}$ digunakan untuk menyaring kotoran berukuran kecil yang terbawa bersama air [10].

Pada penelitian ini telah disepakati untuk menginvestigasi kemampuan dari bahan moringa oleifera dan batu basalt yang digabung sebagai bahan komposit hibrida dalam mengadsorpsi dan mengabsorpsi polutan yang terkandung pada air permukaan secara bersama. Tujuan penelitian menginvestigasi seberapa mampu kedua bahan komposit hibrida mampu mengadsorpsi dan mengabsorpsi polutan yang terkandung didalam air permukaan. Hasil pengujian ditunjukkan melalui karakteristik turbinity dan $\mathrm{pH}$ air. sedangkan kapasitas adsorpsi dan absorpsi dari komposit hibrida di uji menggunakan SEM.

\section{Metode Penelitian}

\subsection{Proses Pembuatan Spesimen}

Pada proses pembuatan spesimen menggunakan metode hot-press pada suhu $200^{\circ} \mathrm{C}$ dan tekanan 2000 psi selama 1 jam. Gambar 1 menunjukkan proses pencetakan komposit hibrida dengan hot-press. Variasi hibridisasi dari bahan pengisi dan pengikat berdasarkan fraksi berat $40 \%$ wt pengisi dan $60 \%$ wt matrik, masing-masing yang ditunjukkan seperti pada tabel 1. Sedangkan untuk geometri dari benda uji dalam penelitian ini adalah seperti ditunjukkan pada gambar 2.

Tabel 1. Komposisi hibrida pengisi dan pengikat

\begin{tabular}{|c|c|c|c|}
\hline \multirow{2}{*}{ Code } & \multicolumn{3}{|c|}{ Komposisi (\%) } \\
\cline { 2 - 4 } & BB & MO & TL \\
\hline KH1 & 40 & 0 & 60 \\
\hline KH2 & 30 & 10 & 60 \\
\hline KH3 & 20 & 20 & 60 \\
\hline KH4 & 10 & 30 & 60 \\
\hline KH5 & 0 & 40 & 60 \\
\hline
\end{tabular}

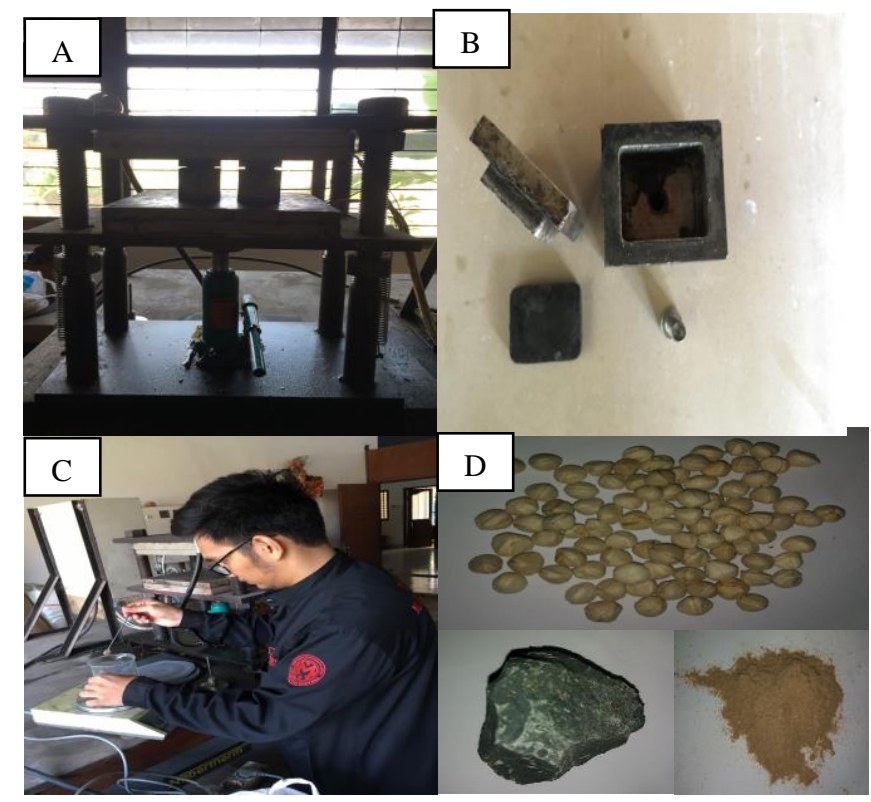

Gambar 1. Proses pencetakan komposit hibrida a) alat hot press, b) alat cetakan, c) mengukur massa bahan d) bahan-bahan

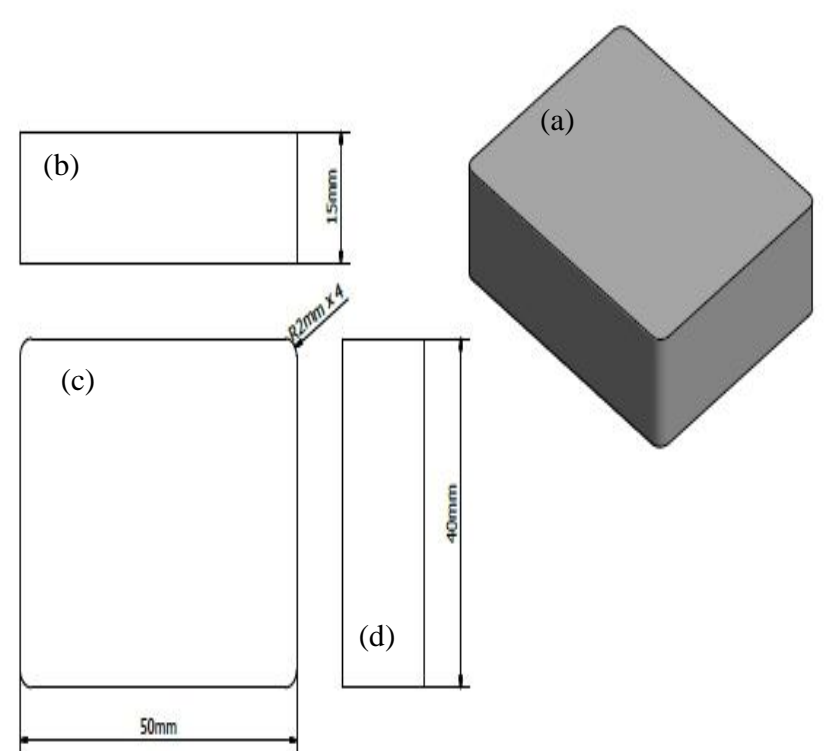

Gambar 2. a) Geometri benda uji b) tampak depan c) tampak atas d) tampak samping 
Gambar 2 menunjukkan dimensi benda uji yang akan digunakan dalam pengujian air permukaan.

\subsection{Turbidity, Mikrobiologi dan Immersion test}

Gambar 3 Menunjukkan proses pengujian turbidity, mikrobiologi dan immersion komposit hibrida pada air permukaan.
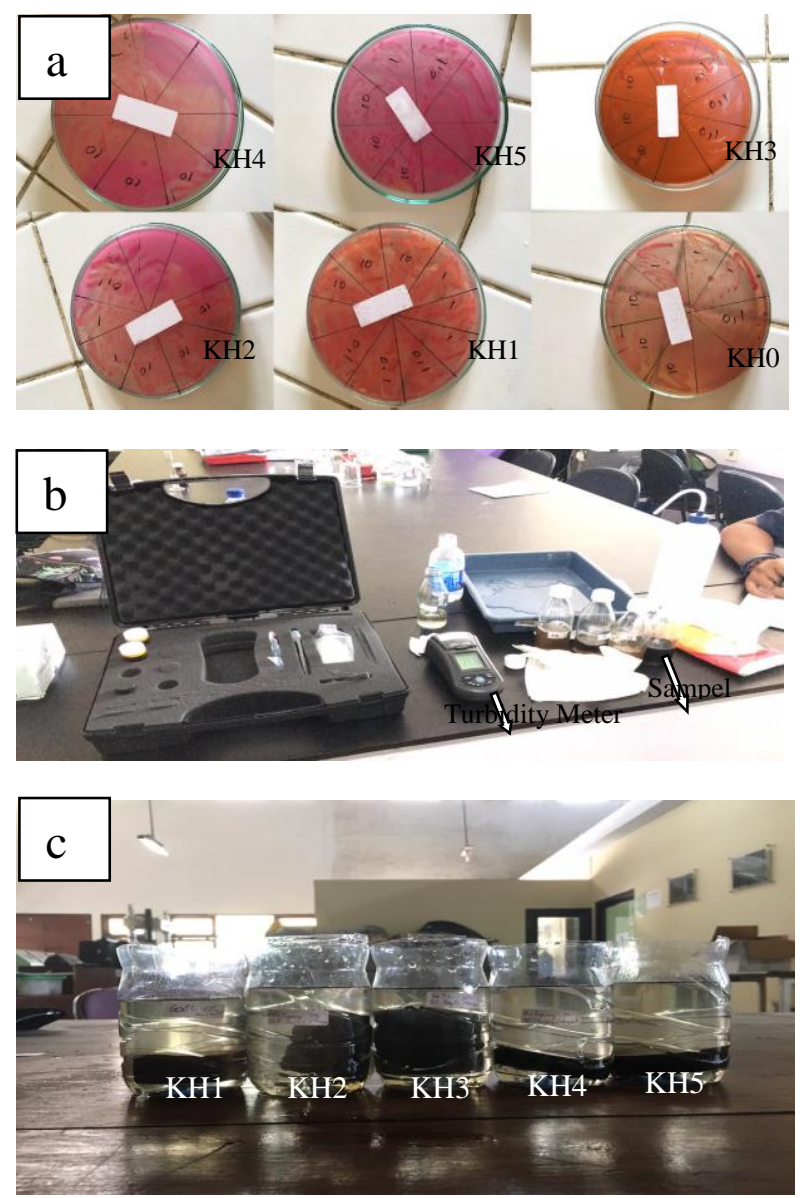

Gambar 3. Tahapan proses pengujian a) Uji Mikrobiologi, b) turbidity test, c) immersion test hari ke-7

Gambar 3 a hingga c menunjukkan pengujian kualitas air dengan absorpsi komposit hibrida yang mengandung moringa oleifera dan batu basalt. Gambar 3a menunjukkan uji mikrobiologi sebagai pengaruh dari batu basalt dan moringa oleifera terhadap pertumbuhan dari bakteri Coliform dan E.coli. Turbidity test merupakan pengujian yang dilakukan untuk mengamati tingkat kekeruhan dari air yang dihasilkan setelah perendaman yang prosesnya ditunjukkan pada gambar 3b. Gambar 3c menunjukkan tahapan pengujian absorpsi komposit hibrida yang direndam selama 14 hari. Pengujian ini dilakukan untuk mengetahui sifat absorpsi komposit hibrida terhadap polutan air.
Hasil uji tes immersion dianalisa dengan menggunakan persamaan sebagai berikut;

$$
m_{u}=((m 1-m 0) / m 0) \times 100 \% .
$$

Dimana;

$\mathrm{m}_{\mathrm{u}}=$ pertambahan massa spesimen setelah diuji (gr)

$\mathrm{m} 0=$ massa awal $(\mathrm{gr})$

$\mathrm{m} 1=$ massa setelah pengujian $(\mathrm{gr})$

\section{Hasil dan Pembahasan}

3.1. Hasil Uji absorpsi dan adsorpsi

Gambar 4 menunjukkan grafik hasil uji immersion komposit hibrida masing-masing variasi.

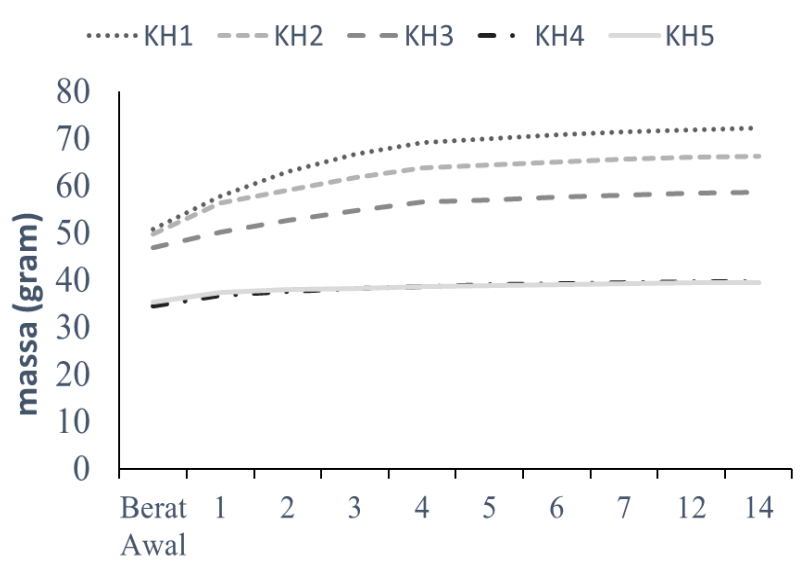

Gambar 4. Grafik immersion komposit hibrida masingmasing variasi

Dapat diamati dari hasil pengujian immersion (gambar 4) bahwa immersion untuk masing-masing komposisi selama 14 hari mengalami kenaikan massa yang signifikan pada hari ke 1 hingga 4 . Selanjutnya, pada hari ke-5 hingga ke-14 kenaikan adalah relatif kecil cenderung konstan. Kemudian, secara ekstrim peningkatan massa terjadi pada komposit hibrida dengan komposisi $\mathrm{KH} 1$, yaitu $40 \%$ dari berat awal, dan sekaligus menjadi yang terberat. Pada komposisi hibrida dengan variasi KH5 mengalami kenaikan 11\% dari massa sebelum pengujiannya. Perilaku penyerapan yang terjadi dari masing-masing komposisi komposit hibrida adalah sangat tergantung pada fraksi berat batu basalt. Hal ini dikarenakan sifat permukaan dari batu basalt yang lebih berpori dari pada moringa oleifera. Pendapat senada juga disampaikan oleh peneliti seperti Robert Treybal yang mengatakan partikel yang dapat diserap adalah partikel yang memiliki diameter lebih kecil dari diameter pori penyerapnya [11]. Selanjutnya dapat disimpulkan bahwa absorpsi banyak dilakukan oleh batu basalt, sedangkan adsorpsi lebih banyak dilakukan oleh moringa oleifera, yang dibuktikan oleh tumbuhnya lendir pada butir moringa. 

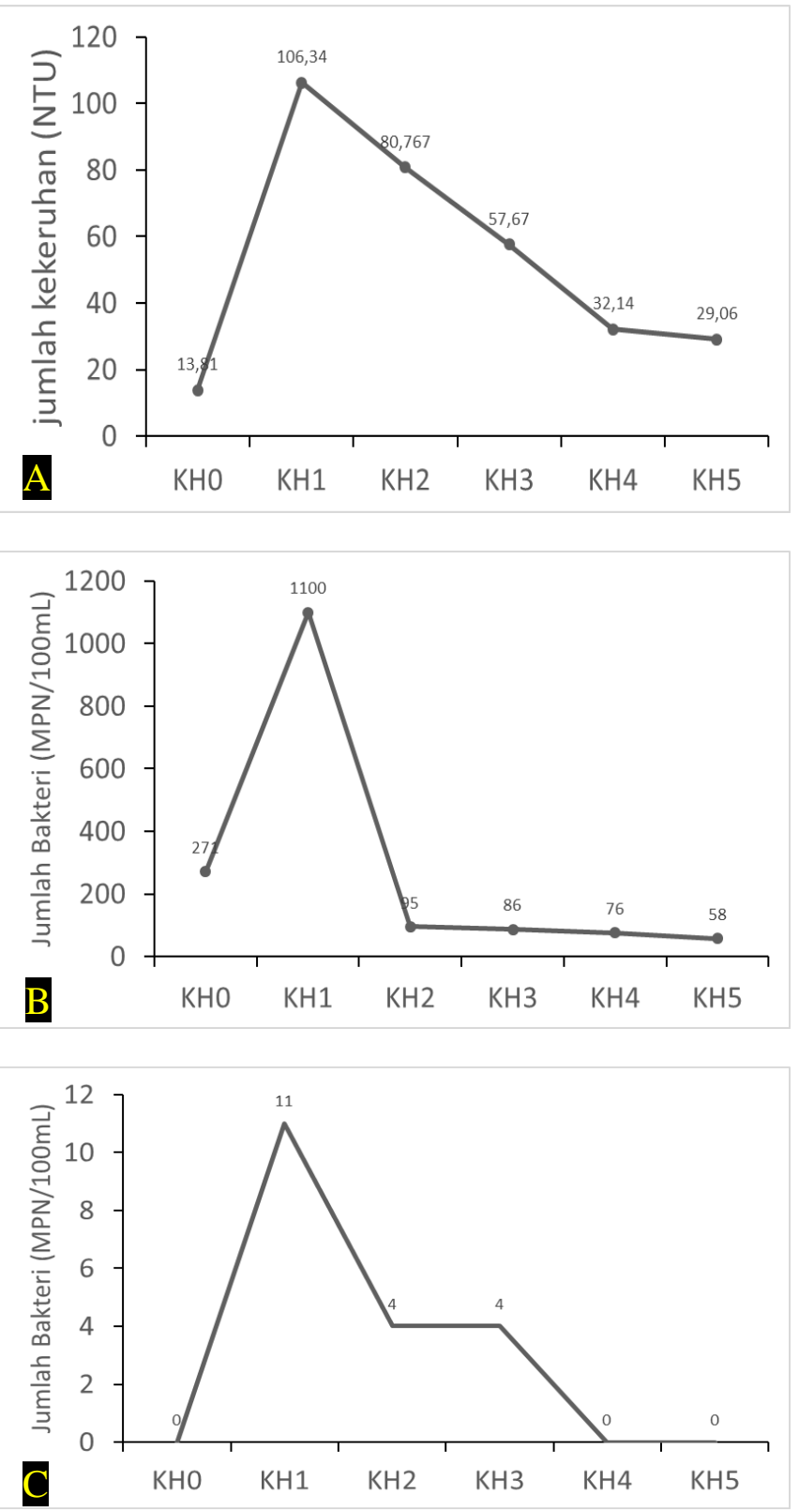

Gambar 5. a) Grafik uji kekeruhan b) Grafik uji bakteri Coliform c) Grafik uji bakteri E.Coli

Gambar 5 menunjukkan hasil analisa mikrobiologi dan kekeruhan pada air permukaan setelah perendaman masing-masing variasi komposit hibrida. Pada grafik 5a yang ditunjukkan dapat diamati nilai kekeruhan air meningkat dikarenakan pengotoran oleh tepung lengket yang digunakan sebagai pengikat komposit hibrida. Kenaikan kekeruhan yang tertinggi terjadi pada variasi komposit hibrida $\mathrm{KH} 1$, yaitu berjumlah 93 NTU. Kemudian untuk kekeruhan $\mathrm{KH} 2$, KH3, KH4 serta KH5 bernilai dibawah 100 NTU. Kandungan mikrobiologi dari air permukaan sebelum dan setelah adsorpsi dan absorpsi komposit hibrida untuk masing-masing komposisi ditunjukkan pada grafik $5 \mathrm{~b}$ dan $5 \mathrm{c}$ Pada pengujian ini, mikrobakteri banyak ditemukan pada batu basalt, sehingga pengurangan mikrobiologi dari air permukaan ditunjukkan oleh komposit hibrida $\mathrm{KH} 1$ yaitu 1100 MPN/100mL untuk bakteri coliform dan 11 $\mathrm{MPN} / 100 \mathrm{~mL}$ E.Coli sedangkan pada $\mathrm{KH} 5$ dengan komposisi $40 \%$ moringa oleifera dan $60 \%$ tepung lengket mempunyai hasil $58 \mathrm{MPN} / 100 \mathrm{~mL}$ coliform dan 0 untuk E.Coli.

\subsection{Hasil Pengamatan SEM dan Analisa EDS}

Gambar 6 menunjukkan pengamatan SEM dan Analisa EDS komposit hibrida pada kondosi sebelum pengujian sedangkan gambar 7 setelah pengujiannya. Hasil analisa EDS ditunjukkan seperti tabel 2 dan 3.

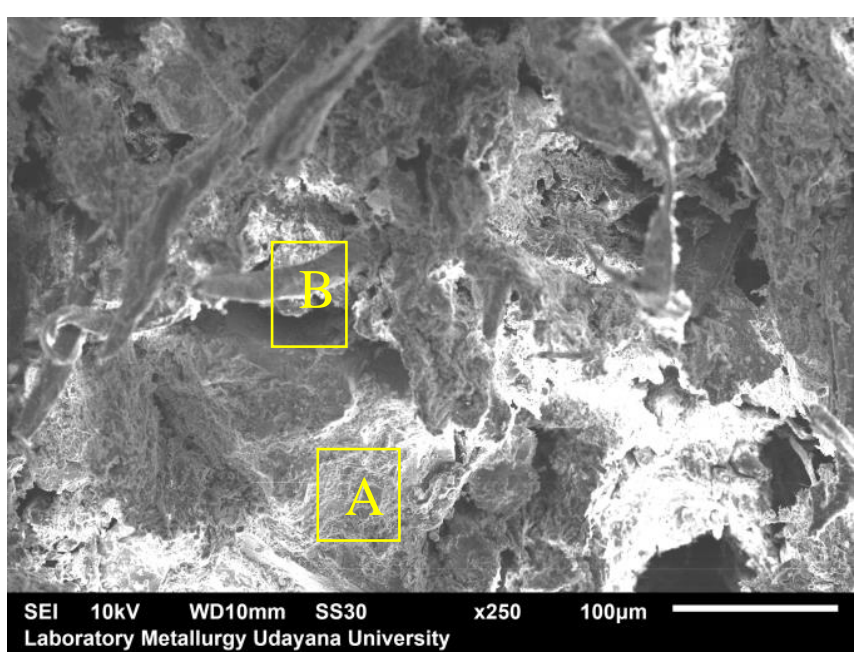

Gambar 6. Pengamatan SEM dan Analisa EDS komposit hibrida pada kondisi sebelum pengujian

Tabel 2a. Analisa EDS sebelum pengujian

\begin{tabular}{|l|l|l|}
\hline Element & keV & Mass (\%) \\
\hline $\mathrm{C}$ & 0.277 & 17.79 \\
\hline $\mathrm{O}$ & 0.525 & 34.6 \\
\hline $\mathrm{Mg}$ & 1.253 & 4.27 \\
\hline $\mathrm{Al}$ & 1.486 & 6.63 \\
\hline $\mathrm{Si}$ & 1.739 & 12.58 \\
\hline $\mathrm{Ta}$ & 1.709 & 24.13 \\
\hline Total & & 100.00 \\
\hline
\end{tabular}

Tabel 2b. Analisa EDS sebelum pengujian

\begin{tabular}{|l|l|l|}
\hline Element & keV & Mass (\%) \\
\hline $\mathrm{C}$ & 0.277 & 45.26 \\
\hline $\mathrm{O}$ & 0.525 & 46.72 \\
\hline $\mathrm{Si}$ & 1.739 & 8.02 \\
\hline Total & & 100.00 \\
\hline
\end{tabular}

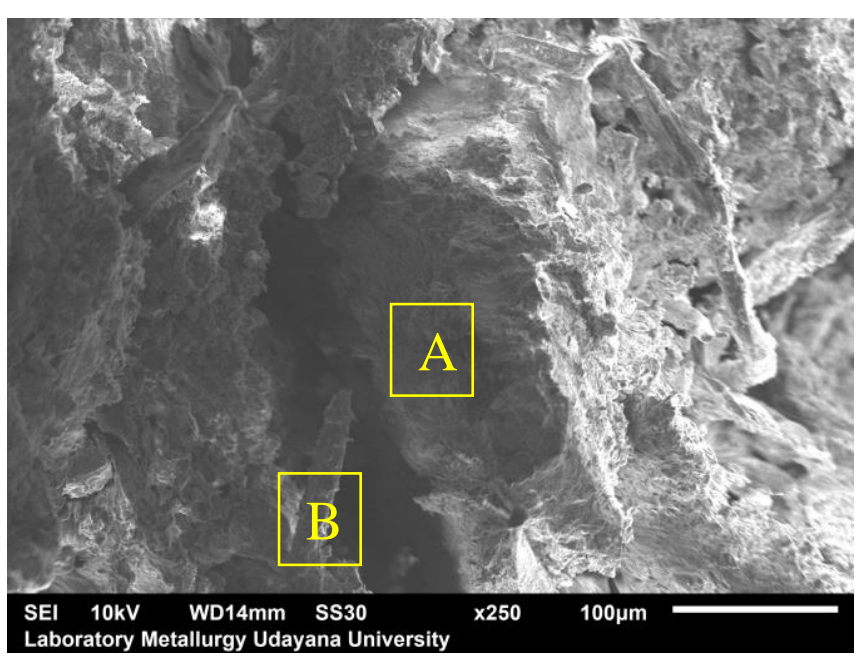


Gambar 7. Pengamatan SEM dan Analisa EDS

komposit hibrida pada kondisi setelah pengujian

Tabel 3a. Analisa EDS setelah pengujian

\begin{tabular}{|l|l|l|}
\hline Element & $\mathrm{keV}$ & Massa $(\%)$ \\
\hline $\mathrm{C}$ & 0.277 & 21.84 \\
\hline $\mathrm{O}$ & 0.525 & 52.33 \\
\hline $\mathrm{Mg}$ & 1.253 & 7.11 \\
\hline $\mathrm{Al}$ & 1.486 & 5.11 \\
\hline $\mathrm{Si}$ & 1.739 & 13.61 \\
\hline Total & & 100.00 \\
\hline
\end{tabular}

Tabel 3b.Analisa EDS setelah pengujian

\begin{tabular}{|l|l|l|}
\hline Element & $\mathrm{keV}$ & Mass (\%) \\
\hline $\mathrm{C}$ & 0.277 & 37.65 \\
\hline $\mathrm{O}$ & 0.525 & 50.89 \\
\hline $\mathrm{Mg}$ & 1.253 & 4.37 \\
\hline $\mathrm{Al}$ & 1.486 & 1.64 \\
\hline $\mathrm{Si}$ & 1.739 & 5.45 \\
\hline Total & & 100.00 \\
\hline
\end{tabular}

Dari hasil pengamatan SEM dan Analisa EDS komposit hibrida sebelum dan sesudah pengujian didapati hasil penyerapan unsur logam pada spesimen $\mathrm{KH} 1$ yaitu $\mathrm{Al}, \mathrm{Mg}$ dan juga Si yang meningkat dan penyerapan tersebut bersifat absorpsi atau penyerapan secara menyeluruh.

\section{Simpulan}

Komposit hibrida dengan bahan pengisi batu basalt (BB) dan moringa oleifera (MO) pada pengikat tepung lengket telah dibuat pada berbagai variasi. Pengujian turbidity dan mikrobiologi untuk air permukaan telah dilakukan. Hasil adsorpsi dan absorpsi dari komposit hibrida diamati dengan SEM. Kesimpulan dari penelitian ini adalah sebagai berikut ;

1. Semakin banyak batu basalt maka unsur logam pada air permukaan semakin terserap. Kondisi ini ditunjukkan pada benda uji KH1. Unsur logam pada air yang terserap meliputi : unsur $\mathrm{Mg} 66 \%$ dan juga Si $8 \%$.

2. Semakin banyak kandungan batu basalt $(\mathrm{KH} 1)$ daya serap kenaikan selama 14 hari semakin besar dibandingan dengan komposit hibrida lainnya mencapai $40 \%$.

3. Semakin banyak kandungan moringa oleifera kandungan bakteri pada air permukaan menurun, sebesar $58 \mathrm{MPN} / 100 \mathrm{~mL}$ dari $271 \mathrm{MPN} / 100 \mathrm{~mL}$ sebelum pengujian yang ditunjukkan pada benda uji $\mathrm{KH} 5$.

4. Dengan hasil tersebut, maka komposit hibrida memiliki kemampuan yang baik dalam mengurangi polutan pada air permukaan dan unggul dalam proses filtrasi yaitu dapat berlaku sebagai adsorpsi dan absorpsi.

\section{Daftar Pustaka}

[1] C.Colombo, L. Vergani and M. Burman, Static and Fatigue Characterisation of New Basalt Fibre Reinforced Composites. Composite Structures, 94 (2012) 1165-1174.

[2] Dian. 2014. Skripsi Adsorpsi Limbah Batik dengan Zeolit Alam. Lampung ; Universitas Lampung.

[3] Pri, Andi. 2013. Kegunaan Zeolit Termodifikasi Sebagai Penyerap Anion dengan Suhu. Semarang; UNDIP.

[4] Hasni, E. dkk. 2015. Activation and Adsorptiob of Natural Zeolit from Banda Aceh. Indonesia Jurnal of Chemistry. 2. 3. 91-97.

[5] Bangun, A. R., Siti Aminah, Rudi Anas Hutahean, M. Yusuf Ritongga, 2013, Pengaruh kadar air, dosis dan lamar pengendapan koagulan serbuk biji kelor sebagai alternatif pengolahan limbah cair industri tahu, Jurnal Teknik Kimia USU, 2 (1), 1-5.

[6] Peraturan Menteri Kesehatan Republik Indonesia Nomor 32 Tahun 2017, Jakarta.

[7] Ulfah, S. Efektivitas biji kelor (Moringa oleifera) terhadap penurunan kadar besi (Fe), [Skripsi]. [Online]. Dari http://digilib.unimus.ac.id. 2009.

[8] Amagloh, F.K \& Benang, Amos. Effectiveness of Moringa oleifera sedd as coagulant for water purification, African Journal of Agricultural Research, [online], Vol. 4 (1), pp. 119-123.

[9] Muyibi, Suleyman A \& Evison L.M. 'Moringa Oleifera Seeds for Softening Hard Water', Water Research [online], Vol. 29, No 4, pp. 1099-1105, 995. Dari: www.elsevier.com/locate/watres. 1994.

[10] Ferri, Rendika. 2011. Paper matakuliah geologi dan mineralogi tanah identifikasi batuan. [Online]. Dari http://kuliahnyok.wordpress.com . 2 Desember 2018.

[11] Treybal, Robert E. 1981. "Mass Transfer Operations", $3^{\text {th }}$ edition, Mc Graw Hill Inc, New York.

[12] Hines, A.L, and Robert N. Maddox (1985), Mass Transfer Fyndamental and Applications. Prentice Hall Inc, New Jersey.

[13] Nasruddin, 2009, Dynamic Modelling and Simulation of a two Bed Silica gel Water Adsorption chiller. Disertastion, Rwth Aachen. 